http://jmscr.igmpublication.org/home/

ISSN (e)-2347-176x ISSN (p) 2455-0450

crossref DOI: https://dx.doi.org/10.18535/jmscr/v7i8.27

Journal Of Medical Science And Clinical Research

\title{
Evaluation of infertile female by one step laparoscopic and hysteroscopic examination
}

\author{
Authors \\ Dr Urvashi Sharma*, Dr Pratibha Verma, Dr Arpita Jain, Dr Sanjay Verma \\ *Corresponding Author \\ Dr Urvashi Sharma
}

Assistant Professor, Department of Obst. \& Gynae, Mahatma Gandhi Medical College \& Hospital, Sitapura, Jaipur, India

\section{Introduction}

Infertility is much investigated and widely studied subject in the field of gynaecology. The reason for this lies in the innate desire of a woman to procreate.

Being labeled 'infertile is devastating to the couple. In the words of one couple, "it feels like being sentenced for a crime you have not committed". For the vast majority of patients infertility is totally unexpected. They look, feel and act normally and everything appears to be functioning well. Suddenly, a young and healthy couple has a medical label, a stigma thrust upon them.

Infertility is the failure of a couple to become pregnant after one year of regular, unprotected intercourse. In both men women the fertility process is complex. About $10 \%$ of couples fall in this category.

\section{Incidence}

- $80-85 \%$ of couple achieve pregnancy if they so desire, within one year of having regular, unprotected intercourse with adequate frequency.

- Another $10 \%$ will achieve the objective by the end of the second year.

- As such, 5-10\% remain without a child by the end of second year.

The increase in demand for infertility services across the world is probably due to the following factors.

1. The tendency of woman to delay child bearing because of their work so that desired reproduction is condensed into a shorter interval than before and at a more advanced age (i.e. 30> or even $>35$ year), which by itself is a negative prognostic factor for the woman's fecund ability.

2. An increase of effective treatments by assisted reproductive techniques (ARTS)

3. An increased awareness of such treatments. Causes of infertility

- Ovulation problems

- Tubal factor \& Peritoneal factors

- Uterine factors

- Cervical factor

- Vaginal factors

- Unexplained infertility

- Male infertility

Conventional methods of investigations in female include:

- Routine blood tests including hormonal assays. Ultrasound. 
- Hysterosalpingography

- Endometrial biopsy.

But none of the above mentioned investigations are decisive regarding the diagnosis and final treatment of the patients. HSG, though gives an idea about the tubal patency and uterine interior but is associated with false positive and false negative results.

As a diagnostic tool, a combined laparoscopic and hysteroscopic examination is optimum means of evaluating infertility. Done at one sitting they offer therapeutic advantage over diagnostic aid.

Laparoscopy permits direct visualization of uterus, adnexas, anterior and posterior pouches, peritubal adhesions and endometriosis if present. Instillation of dye methylene blue through a cannula in the cervix permits direct visualization of its path through tubes and the exact site of block if any. Hysteroscopy permits the inspection of the cervical canal, uterine cavity and evaluation of the tubal ostium and the proximal intramural segment of the fallopial tubes. Hysteroscopy accurately defines lesions such as submucus fibroids, polyps and synechiae.

Gynaecological endoscopic surgeries thus have changed and improved the results of infertility evaluation and treatment.

\section{Aims and Objective}

The major goals involved in the evaluation of infertile female by one step laparoscopic and hysteroscopic examination are:

1. To observe various abnormalities on laparoscopic and hysteroscopic evaluation of infertile female.

2. Identification of the cause contributing to the infertile state.

3. Correlation of the causes of infertility if possible.

4. Providing accurate information, education $\&$ counseling to both the partners, explain the nature of therapy.

\section{Material and Methods}

The present study included cases of primary and secondary infertility attending the outpatient department of Obstetrics and Gynaecology at Mahatma Medical College \& Hospital, Jaipur, evaluated by one step laparoscopic and hysteroscopic examination. The study was conducted from May 2017 to April 2018.

Design: Prospective study

Patients: 200 cases.

\section{Inclusion Criteria}

1. Infertility, primary or secondary.

2. Normal hormonal profile.

3. Normal malefactor.

4. No obvious pelvic pathology.

\section{Exclusion Criteria}

1. Contraindications to laparoscopy/ hysteroscopy

2. Contra indications to general anaesthesia.

3. Marital life $<2$ years.

\section{Observation and Results \\ Observation}

A total of 200 Laparoscopies and hysteroscopies were done.

\section{Division of patients}

All patients were divided in to two groups: Group I - 150 patients with primary infertility Group II 50 patients with secondary infertility

Table No. 1 Distribution according to age group

\begin{tabular}{|l|c|c|c|c|c|c|}
\hline \multirow{2}{*}{$\begin{array}{l}\text { Age group (In } \\
\text { Yrs) }\end{array}$} & \multicolumn{2}{|c|}{ Primary infertility } & \multicolumn{2}{c|}{ Secondary Infertility } & \multicolumn{2}{c|}{ Both } \\
\cline { 2 - 7 } & No. & $\%$ & No. & \% & No. & \% \\
\hline $20-24$ & 47 & 31.33 & 10 & 20.00 & 57 & 28.50 \\
\hline $25-29$ & 84 & 56.00 & 27 & 13.50 & 111 & 55.50 \\
\hline $30-34$ & 16 & 10.67 & 10 & 20.00 & 26 & 13.00 \\
\hline$\geq 35$ & 3 & 2.00 & 3 & 1.50 & 6 & 3.00 \\
\hline Total & 150 & 100.00 & 50 & 100.00 & 200 & 100.00 \\
\hline
\end{tabular}

The age of the patients ranged from 21 to 38 years. The youngest was 21 years and the oldest infertility group was $26.30 \pm 3.10 \&$ secondary infertility $27.72 \pm 3.75$ years. was 38 years in both groups. Mean age at primary 
Table No. 2 Distribution according to religion, Area \& Socio-economic status

\begin{tabular}{|c|c|c|c|c|c|c|}
\hline \multirow[b]{2}{*}{ Religion } & \multicolumn{2}{|c|}{ Primary infertility } & \multicolumn{2}{|c|}{ Secondary Infertility } & \multicolumn{2}{|c|}{ Both } \\
\hline & No. & $\%$ & No. & $\%$ & No. & $\%$ \\
\hline Hindu & 140 & 93.33 & 48 & 96.00 & 188 & 94.00 \\
\hline Muslim & 10 & 6.67 & 2 & 4.00 & 12 & 6.00 \\
\hline Total & 150 & 100.00 & 50 & 100.00 & 200 & 100.00 \\
\hline \multicolumn{7}{|l|}{ Area } \\
\hline Rural & 93 & 62.00 & 41 & 82.00 & 134 & 67.00 \\
\hline Urban & 57 & 38.00 & 9 & 18.00 & 66 & 33.00 \\
\hline Total & 150 & 100.00 & 50 & 100.00 & 200 & 100.00 \\
\hline \multicolumn{7}{|l|}{ Socio-economic status } \\
\hline Class I Upper & 6 & 4.00 & 00 & 00.00 & 6 & 3.00 \\
\hline Class II Upper Middle & 45 & 30.00 & 12 & 24.00 & 57 & 28.50 \\
\hline Class III Lower Middle & 91 & 60.67 & 30 & 60.00 & 121 & 60.50 \\
\hline Class I Upper Lower & 8 & 5.33 & 08 & 16.00 & 16 & 08.00 \\
\hline Total & 150 & 100.00 & 50 & 100.00 & 200 & 100.00 \\
\hline
\end{tabular}

Table No. 3 Distribution according to Associated Complained

\begin{tabular}{|l|c|c|}
\hline & Group I (\%) & Group II (\%) \\
\hline Pain in abdomen & 12 & 15 \\
\hline White discharge PV & 5 & 7 \\
\hline Backache & 2 & 4 \\
\hline AUB & 22 & 24 \\
\hline
\end{tabular}

Table No. 4 Distribution of various Laparoscopic abnormalities of female

\begin{tabular}{|c|c|c|c|c|c|c|c|}
\hline \multirow[t]{2}{*}{ Type of Pathology } & \multicolumn{2}{|c|}{ Infertility } & \multirow[b]{2}{*}{ Total } & \multirow{2}{*}{$\chi^{2}$} & \multirow[b]{2}{*}{ d.f } & \multirow{2}{*}{$\begin{array}{c}P- \\
\text { value }\end{array}$} & \multirow[b]{2}{*}{ Significance } \\
\hline & Primary & Secondary & & & & & \\
\hline Pelvic adhesions & $\begin{array}{c}54 \\
(36.00)\end{array}$ & $\begin{array}{c}20 \\
(40.00)\end{array}$ & $\begin{array}{c}74 \\
(37.00)\end{array}$ & 0.382 & 1 & $>.05$ & NS \\
\hline Tubercles & $\begin{array}{c}50 \\
(33.33)\end{array}$ & $\begin{array}{c}20 \\
(40.00)\end{array}$ & $\begin{array}{c}70 \\
(35.00)\end{array}$ & 0.732 & 1 & $>.05$ & NS \\
\hline PID & $\begin{array}{c}36 \\
(24.00)\end{array}$ & $\begin{array}{c}14 \\
(28.00)\end{array}$ & $\begin{array}{c}50 \\
(25.00)\end{array}$ & 0.320 & 1 & $>.05$ & NS \\
\hline Endometriosis & $\begin{array}{c}26 \\
(17.33)\end{array}$ & $\begin{array}{c}2 \\
(4.00)\end{array}$ & $\begin{array}{c}28 \\
(14.00)\end{array}$ & 4.485 & 1 & $<.05$ & Sig \\
\hline PCOD & $\begin{array}{c}22 \\
(14.67)\end{array}$ & $\begin{array}{c}4 \\
(8.00)\end{array}$ & $\begin{array}{c}26 \\
(13.00)\end{array}$ & 5.990 & 1 & $<.02$ & Sig \\
\hline To mass & $\begin{array}{c}14 \\
(9.33)\end{array}$ & $\begin{array}{c}6 \\
(12.00)\end{array}$ & $\begin{array}{c}20 \\
(10.00)\end{array}$ & 0.296 & 1 & $>.05$ & NS \\
\hline Fibroids & $\begin{array}{c}10 \\
(6.67)\end{array}$ & $\begin{array}{c}2 \\
(4.00)\end{array}$ & $\begin{array}{c}12 \\
(6.00)\end{array}$ & 0.118 & 1 & $>.05$ & NS \\
\hline Fimbrial cyst & $\begin{array}{c}4 \\
(2.67)\end{array}$ & $\begin{array}{c}0 \\
(0.00)\end{array}$ & $\begin{array}{c}4 \\
(2.00)\end{array}$ & - & & & \\
\hline No abnormalities & $\begin{array}{c}19 \\
(12.67)\end{array}$ & $\begin{array}{c}9 \\
(18.00)\end{array}$ & $\begin{array}{c}28 \\
(14.00)\end{array}$ & 0.886 & 1 & $>.05$ & NS \\
\hline
\end{tabular}

Table No. 5 Distribution according to CPT in female

\begin{tabular}{|l|c|c|c|}
\hline \multirow{2}{*}{ CPT } & \multicolumn{2}{|c|}{ Type of Infertility } & \multirow{2}{*}{ Total } \\
\cline { 2 - 3 } & Primary & Secondary & 134 \\
Bilateral positive & 100 & 34 & $(67.00)$ \\
\hline & $(66.67)$ & $(68.00)$ & 14 \\
Negative in right tube & 12 & 2 & $(7.00)$ \\
\hline & $(8.00)$ & $(4.00)$ & 10 \\
Negative in left tube & 8 & 2 & $(5.00)$ \\
\hline & $(5.33)$ & $(4.00)$ & 42 \\
Bilateral negative & 30 & 12 & $(21.00)$ \\
\hline & $(20.00)$ & $(24.00)$ & 200 \\
Total & 150 & 50 & $(100.00)$ \\
\hline
\end{tabular}


$66.67 \%$ patients in group I and $68 \%$ of group II showed bilateral free spill on chromopertubation. $20 \%$ of group I and $24 \%$ patients of group II did not show free spill either unilaterally or bilaterallay.

Table No. 6 Various hysteroscopic abnormalities of female

\begin{tabular}{|c|c|c|c|c|c|c|c|}
\hline \multirow{2}{*}{$\begin{array}{l}\text { Hysteroscopic } \\
\text { abnormalities }\end{array}$} & \multicolumn{2}{|c|}{ Infertility } & \multirow[t]{2}{*}{ Total } & \multirow{2}{*}{$x^{2}$} & \multirow[t]{2}{*}{ d.f } & \multirow{2}{*}{$\begin{array}{c}\text { P- } \\
\text { value }\end{array}$} & \multirow{2}{*}{ Significance } \\
\hline & Primary & Secondary & & & & & \\
\hline $\begin{array}{c}\text { No } \\
\text { abnormalities }\end{array}$ & $\begin{array}{c}76 \\
(50.67) \\
\end{array}$ & $\begin{array}{c}24 \\
(48.00) \\
\end{array}$ & $\begin{array}{c}100 \\
(50.00)\end{array}$ & 0.107 & 1 & $>.05$ & $\mathrm{NS}$ \\
\hline $\begin{array}{l}\text { Intrauterine } \\
\text { adhesions }\end{array}$ & $\begin{array}{c}44 \\
(29.33)\end{array}$ & $\begin{array}{c}16 \\
(32.00)\end{array}$ & $\begin{array}{c}60 \\
(30.00)\end{array}$ & 0.127 & 1 & $>.05$ & NS \\
\hline $\begin{array}{l}\text { Stenosed internal } \\
\text { OS }\end{array}$ & $\begin{array}{c}20 \\
(13.33)\end{array}$ & $\begin{array}{c}10 \\
(20.00)\end{array}$ & $\begin{array}{c}30 \\
(15.00)\end{array}$ & 1.307 & 1 & $>.05$ & $\mathrm{NS}$ \\
\hline Congestion & $\begin{array}{c}22 \\
(14.67)\end{array}$ & $\begin{array}{c}6 \\
(12.00)\end{array}$ & $\begin{array}{c}28 \\
(14.00)\end{array}$ & 0.221 & 1 & $>.05$ & NS \\
\hline Tubercles & $\begin{array}{c}16 \\
(10.67)\end{array}$ & $\begin{array}{c}4 \\
(8.00)\end{array}$ & $\begin{array}{c}22 \\
(11.00)\end{array}$ & 0.074 & 1 & $>.05$ & NS \\
\hline $\begin{array}{c}\text { Polypoidal } \\
\text { endometreium }\end{array}$ & $\begin{array}{c}10 \\
(6.67)\end{array}$ & $\begin{array}{c}2 \\
(4.00)\end{array}$ & $\begin{array}{c}12 \\
(6.00)\end{array}$ & 0.118 & 1 & $>.05$ & NS \\
\hline Left ostia fibrosed & $\begin{array}{c}2 \\
(1.33)\end{array}$ & $\begin{array}{c}4 \\
(8.00)\end{array}$ & $\begin{array}{c}6 \\
(3.00)\end{array}$ & 0.009 & 1 & $>.05$ & NS \\
\hline Right ostia fibrosed & $\begin{array}{c}6 \\
(4.00)\end{array}$ & $\begin{array}{c}2 \\
(4.00)\end{array}$ & $\begin{array}{c}8 \\
(4.00)\end{array}$ & 0.000 & 1 & $>.05$ & NS \\
\hline $\mathrm{B} / \mathrm{L}$ ostia not seen & $\begin{array}{c}6 \\
(4.00) \\
\end{array}$ & $\begin{array}{c}4 \\
(8.00) \\
\end{array}$ & $\begin{array}{c}10 \\
(5.00)\end{array}$ & 0.561 & 1 & $>.05$ & NS \\
\hline Incomplete septum & $\begin{array}{c}2 \\
(1.33) \\
\end{array}$ & $\begin{array}{c}0 \\
(0.00)\end{array}$ & $\begin{array}{c}2 \\
(1.00)\end{array}$ & - & & & \\
\hline
\end{tabular}

No abnormality was detected in $50.6 \%$ of group I and $48 \%$ of groupie. Most common finding in both groups was interauterine adhesion, $29.33 \%$ in group I and 32\% in group II. The p-values for various abnormalities were $>0.05$, which is not significant.

Table No. 7 Procedure performed

\begin{tabular}{|l|c|c|c|}
\hline \multirow{2}{*}{ Procedure } & \multicolumn{2}{|c|}{ Type of Infertility } & \multirow{2}{*}{ Total } \\
\cline { 2 - 3 } & Primary & Secondary & \\
\hline aparoscopic adhesiolysis & 52 & 18 & 70 \\
& $(34.67)$ & $(36.00)$ & $(35.00)$ \\
\hline Intrauterine adhesiolysis & 36 & 14 & 50 \\
& $(24.00)$ & $(28.00)$ & $(25.00)$ \\
\hline LOD & 22 & 4 & 26 \\
& $(14.67)$ & $(8.00)$ & $(13.00)$ \\
\hline Cystectomy & 20 & 0 & 20 \\
& $(13.33)$ & $(0.00)$ & $(10.00)$ \\
\hline Myomectomy & 8 & 2 & 10 \\
& $(5.33)$ & $(4.00)$ & $(5.00)$ \\
\hline Polypectomy & 8 & 2 & 10 \\
& $(5.33)$ & $(4.00)$ & $(5.00)$ \\
\hline Excision Septa & 2 & 0 & 2 \\
& $(1.33)$ & $(0.00)$ & $(1.00)$ \\
\hline
\end{tabular}

\section{Discussion}

Problem of infertility is on a rising trend. Endoscopic evaluation of the pelvic and intrauterine factors is indispensable for infertility evaluation. It helps in diagnosis as well as treatment at the same sitting. We observed various abnormalities on laparoscopy. Tuberculosis, PID, Endometriosis, PCOD and Pelvic adhesions were the major one.

\section{A) Tuberculosis}

1. In our study, the incidence of tuberculosis was $35 \%$ (primary $33.3 \%$, secondary 
40\%). Various findings observed are presence of tubercles on tubes, peritoneum, uterus, gut and endometrium, caseation granuloma, adhesions, beaded tube, blocked tube, hydrosalpinx, TO mass, pelvic congestion and fluid in peritoneal cavity.

2. Tuberculosis is a major cause of infertility especially in South East Asian countries. The incidence of genital tuberculosis in India is $19 \% .^{46}$ Female genital $\mathrm{TB}$ is typically understood as a disease of young women with $80-90 \%$ of cases diagnosed in a patient of 20-40 yearsold.

3. Infertility is the commonest presentation of genital TB with reported incidence of infertility being between $40-80 \%$.

4. In our study the high incidence of tuberculosis was found because patients in India living in an environment where pulmonary tuberculosis is rampant. Further $\%$ of low socio economic group and less educated patients were more and most of the patients belonging to rural area in ourstudy.

\section{B) PID}

1. Data from industrialized countries indicate that $10-40 \%$ of women with untreated chlamydial or gonococcal infection develop symptomatic PID and that up to one quarter of these with PID will become infertile.

2. In the pre antibiotic era the post PID infertility rates were as high as $60-70 \% .^{61}$

3. After one episode of laparoscopically proven PID 8\% women develop infertility. The figure rises to $40 \%$ after 3 episodes. ${ }^{62}$

4. Incidence of PID in our study was $25 \%$ (primary 24\%, secondary 28\%).

5. Most common pathogens causing PID are Chlamydia trachomatis, Neisseria gonorrhoeae

6. In our study incidence of PID is high. It can be explained by most of the patients belonging to low SES group.
C) Endometriosis - In our study the incidence of endometriosis was $14 \%$ (primary $17.33 \%$, secondary 4\%). This includes all the stages of endometriosis ranging from mild, moderate to severe. The commonest site was found to be the ovaries, uterosacral ligaments and POD.

Kichukova D et al. in 2005 established endometriosis is an unexpected finding during laparoscopy on sterile women. ${ }^{65}$ His study was retrospective and included 20 years period of time (1976-1996) 912 patients were evaluated on whom laparoscopy was performed. Cases with endometriosis were $25 \%$. He concluded that diagnosis of endometriosis by laparoscopy effectively helps in further treatment of sterile women.

Godinjak Z, Idrizbegovic E 2008 conducted a retrospective study in 360 infertile women who underwent combined diagnostic laparoscopy \& hysteroscopy. In his study endometriosis was found in $14.16 \%$. This matches with our results.

D) PCOS is a well established cause of infertility. It results in anovulation and thus affects fertility. Incidence of PCOD in our study was $13 \%$ (primary $14.67 \%$, secondary $8 \%$ ).

SAK Amar in 2004 did a study on LOD in women with PCOS. In his study $57 \%$ ovulated without induction drugs.

Li et al. reported a cumulative pregnancy rate of $54 \%$ at 12 months follow up after LOD. ${ }^{68}$

E) Fibroid In our study $\%$ of fibroid uterus was $5 \%$ (primary $5.33 \%$, secondary $4 \%$ ). All were subserous fibroid.

Godinjak Z, Idrizbegovic E found myoma in his study in $11.65 \%$.

\section{Hysteroscopic Abnormalities}

There were numerous abnormalities encountered on hysteroscopy. Intrauterine adhesion, polypoidal endometrium, ostial fibrosis, congestion \& tubercles were the major one.

1) Incidence of intrauterine adhesions $30 \%$ (primary $29.33 \%$, secondary $32 \%$ ).

2) According to study by Josef Shalev et al. 
intrauterine adhesions were seen in $13.8 \%$ of infertile women by hysteroscopy.

3) Study by Neena Malhotra \& Maya Sood showed $25 \%$ of their patients to have adhesions on hysteroscopy.

4) Tiufekchieva E et al. 2006 found intrauterine adhesions in $50 \%$ patients. ${ }^{3}$.

5) In our study incidence of Polypoidal endometrium was $6 \%$ (primary $6.67 \%$, secondary $4 \%$ ).

6) Sergio Reis et al. evaluated 65 patients by hysteroscopy and showed endometrial Polyp in $10 \%$ of his patients. ${ }^{71}$

7) Godinjak $\mathrm{Z}$ et al. in 2008 found polypoidal endometrium in $7.22 \%{ }^{66}$

\section{Conclusion}

This study one step laparoscopic and hysteroscopic evaluation in infertility, was carried out in the department of Obstetrics and Gynaecology of Mahatma Gandhi Medical College \& Hospital, from May 2017 to April 2018.

- Maximum patients were in 25 to 29 years of age group.

- Mean age of patients in two groups varied between 26.3 to 27.72 years.

- $94 \%$ were Hindus and 6\% were Muslims.

- $67 \%$ patients were from rural area.

- $60.5 \%$ patients were from class III (lower middle) socioeconomic status.

- Duration of infertility in both groups was ranging from 2.5 to 16years.

- Mean duration of infertility varied between 6.05 to 6.18 years.

- Normal menstrual history was present in $77 \%$ of cases.

- Past history of tuberculosis was present in $6 \%$ patients. Previous surgery (left salpingoopherectomy) for chocolate cyst in two patients of group I. Past history of puerperal sepsis was found in two patients of group II.

\section{Laparoscopic Abnormalities}

- Common findings obtained on laparoscopy were pelvic adhesions, tuberculosis. PID, endometriosis and PCOS.

- Normal pelvic findings were seen in $14 \%$.

- Tuberculosis was present in $35 \%$. Various findings like tubercles, extensive pelvic adhesions, hydrosalpinx were found.

- PID was found in $25 \%$ of cases.

- Pelvic adhesions were found in $37 \%$.

- Endometriosis of varying degree was found in $14 \%$.

- PCOS was found in13\%.

- Fibroid (subserous) were present in5\%.

- On chromopertubation (CPT) in 67\%, bilateral spill was seen. CPT was negative unilaterally in $12 \%$. Bilateral negative CPT was found $21 \%$.

\section{Hysteroscopic Abnormality}

- Findings were normal in 50\%cases.

- Major hysteroscopic abnormality were intrauterine adhesions, stenosed internal os, ostial fibrosis, tubercles and polypoidal endometrium.

- $30 \%$ had intrauterine adhesions.

- $15 \%$ had stenosed internalos.

- In $83 \%$ patients bilateral ostia seen. In rest of the patients either unilateral or bilateral ostia fibrosed or could not be seen due to adhesions.

- $14 \%$ had congestion inendometium.

- $11 \%$ had scanty endometrium.

- $11 \%$ had tubercles.

- $6 \%$ had polypoid endometrium.

- $1 \%$ had partial septa.

- Various procedures done were laparoscopic and hysteroscopic adhesiolysis, ovarian drilling, cystectomy, myomectomy, polypectomy and excision of septa

- Plan of management was in various forms like AKT, long term antibiotics, ovulation induction/IUI/IVF as per requirement, GnRh/OCPs, myomectomy, polypectomy, excision of septa. 
Thus we can say that one steps laparoscopic and hysteroscopic evaluation in female infertility has a diagnostic as well as therapeutic edge over other investigations.

\section{Bibliography}

1. Varma TR. Genital tuberculosis and subsequent fertility. Int J Gynaecol obstet 1991; 1(35):1-11.

2. Schaefer, George. Female genital tuberculosis. Clin obstet and Gynaecol 1976; 19:233-39.

3. Bazaz-Malik G, Maheshwari B, Lal N. Tuberculosis endometritis: a clinicopathological study of 1000 cases. $\mathrm{Br}$ J Obstet Gynaecol 1983; 90:84-86.

4. Bobhate SK, Kadar GP, Khan A, Grover S. Female genital tuberculosis. A pathological appraisal. J Obstet Gynaecol India 1986; 36:676-680.

5. Bhide AG, Parulekar SV, Bhattacharya MS. Genital tuberculosis in females. J Obstet Gynaecol India 1987; 37:576-578.

6. Chhabra S. Genital tuberculosis - a baffling diseases. J Obstet Gynaecol India 1990; 40:569-573.

7. Nagpal M, Pal D. Genital tuberculosis - a diagnostic dilemma in OPD patients. $\mathbf{J}$ Obstet Gynaecol India 2001; 51:127-131.

8. Jindal UN. An algorithmic approach to female genital tuberculosis causing infertility. Int J Tuberc Lung Dis 2006; 10:1045-1050.

9. Westrom L. Incidence, prevalence and trends of acute pelvic inflammatory disease and its consequences in industrialized countries. Am J Obstet Gynaecol 1980; 138:380-392.

10. Platt R, Rice PA, McCormack WM. Risk of acquiring gonorrhoea and prevalence of abnormal adnexal findings among women recently exposed to gonorrhoea JAMA 1983; 250:3205-3209.

11. Westrom L, Mardh P-A. Salpingitis in: Holmes KK, Mardh P-A, Sparling PF et al., eds. Sexually transmitted disease. New
York: McGraw Hill, 1984;615-632.

12. Westrom LV, Joesoef R, Reynolds G, Thomson SE. Pelvic inflammatory disease and fertility. A cohort study of 1844 women with laparoscopically verified disease and 657 control women with normal laparoscopic results. Sex Trans Dis 1992; 19:185-192.

13. Kichukova D, Uchikova E, Velevski V. Endometriosis as anunexpected finding during laparoscopy on sterile women. Department of Obstetrics and Gynaecology, High Medical, Plovdiv 2000; 39(3):25-6.

14. Godinjak Z, Idrizbegovic E. Should diagnostic hysteroscopy be a routine procedure during diagnostic lap in infertile women? Journal of Basic Med Sci, 2008 Feb; 8(1):44-47.

15. SAK Amer, TC Li, WL Ledger. Ovulation induction using Laparoscopic ovarian drilling in women with PDOD: predictors of success. Human reproduction 2004; 19(8):1719-1724.

16. Li TC Saravelos H, Chow MS, Chisabingo R, Cooke ID. Factors affecting the outcome of laparoscopic ovarian drilling for polycystic ovarian syndrome in women with anovulatory infertility. British Journal of obstetrics and gynaecology. 1998; 105:338-44.

17. Josef Shalev, Israel Meizner, Itay BarHava, Dov Dicker, Reuben Mashiach, Zion Ben Rafael. Predictive value of TVS performed before routine diagnostic hysteroscopy for evaluation of infertility. Fertility \& Sterility Feb 2000; 73(2):412417.

18. Neena Mahlotra, Maya Sood. Role of hysteroscopyin infertility in infertile women. Journal Indian medical association Sep.1997; 95(9):499.

19. G. de Candolleand J. Bouquett de Jolinier. Management of tubal infertility. Infertility and Gynaecologic Endocrinology Clinic. 1988May.

20. Sergio Reis Soares, Marcos Messala 
Batista Barbosa dos Reis, Aroldo Fernando Camargos. Diagnostic accuracy of sonohysterography, transvaginal sonography and hysterosalpingography in patients with uterine cavity disease. Fertility and Sterility Feb 2000; 73(2):406411. 